\title{
Faktor yang Memengaruhi Pemberian ASI Eksklusif pada Bayi Gukup Bulan yang Dilakukan Inisiasi Menyusu Dini [IMD]
}

\author{
Reni Fahriani, Rinawati Rohsiswatmo, Aryono Hendarto \\ Departemen Ilmu Kesehatan Anak, Fakultas Kedokteran Indonesia Rumah Sakit Cipto Mangunkusumo, \\ Jakarta
}

\begin{abstract}
Latar belakang. Air susu ibu merupakan nutrisi ideal untuk bayi. World Health Organization (WHO) menganjurkan pemberian ASI eksklusif hingga 6 bulan. Data Survey Demografi dan Kesehatan Indonesia (SDKI) tahun 2003 dan 2007 menunjukkan angka ASI eksklusif di Indonesia cenderung turun. Beberapa penelitian menunjukkan terdapat beberapa faktor yang memengaruhi pemberian ASI eksklusif.

Tujuan. Mengetahui proposi ASI eksklusif pada bayi yang dilakukan IMD, dan mengetahui faktor-faktor yang memengaruhinya.

Metode. Penelitian potong lintang analitik dengan pengumpulan data melalui wawancara pada bulan Juni-September 2012. Subjek penelitian adalah ibu yang memiliki anak berusia 0-6 bulan yang datang ke Poliklinik Anak RS St. Carolus Jakarta. Analisis statistik dengan uji Kai kuadrat dan regresi logistik.

Hasil. Dilakukan penelitian pada 120 subjek. Proporsi ASI eksklusif 75\%, sebagian besar merupakan primipara (56,7\%). Kelahiran secara spontan 65,8\%. Subjek yang memiliki tingkat pendidikan tinggi $73,3 \%$ dan 59,2\% merupakan ibu bekerja. Subjek yang termasuk ke dalam status sosial ekonomi tinggi 45\%, sisanya berada di sosial ekonomi rendah $(4,2 \%)$, dan menengah $(50,8 \%)$. Sebagian besar subjek $(73,3 \%)$ telah memperoleh konseling ASI. Faktor yang paling bermakna memengaruhi ASI eksklusif berturut-turut, yaitu faktor psikis ibu, dukungan keluarga, pengetahuan tentang ASI eksklusif, dan konseling ASI.

Kesimpulan. Proporsi ASI eksklusif pada bayi cukup bulan yang dilakukan IMD di RS St Carolus adalah 75\%. Faktor yang terbukti memengaruhi pemberian ASI eksklsusif adalah faktor psikis ibu (keyakinan ibu terhadap produksi ASI), dukungan keluarga, pengetahuan ibu yang benar tentang ASI eksklusif, dan konseling ASI. Sari Pediatri 2014;15(6):394-402.
\end{abstract}

Kata kunci: ASI eksklusif, inisiasi menyusu dini, faktor yang memengaruhi

\footnotetext{
Alamat korespondensi:

DR. Dr. Rinawati Rohsiswatmo, Sp.A(K). RSUPN Dr. Cipto Mangunkusumo. Jl Diponegoro no. 71, Jakarta Pusat. Telp. (021) 3154020. Fax.(021)3154020 E-mail: rinawati@idai.or.id / reni_ fahriani@idai.or.id
}

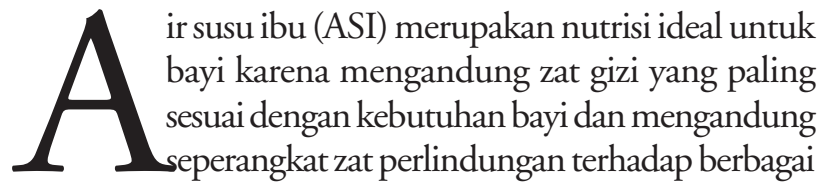


penyakit.1-3 World Health Organization (WHO) menganjurkan bayi diberikan ASI eksklusif selama 6 bulan pertama. ${ }^{4}$ Pemerintah Indonesia sendiri telah mencanangkan anjuran WHO sejak tahun 2004 melalui dikeluarkannya Kepmenkes No.450/MENKES/IV/2004 tentang pemberian ASI eksklusif pada bayi di Indonesia dan Undang-undang (UU) No. 36 pasal 128 tahun 2009 tentang kesehatan. ${ }^{5,6}$

Survey Demografi dan Kesehatan Indonesia (SDKI) tahun 2002-2003 menunjukkan jumlah bayi yang menyusu pada 1 jam pertama setelah lahir (inisiasi menyusu dini, IMD) baru mencapai 3,7\% sementara pemberian ASI eksklusif sampai dengan usia 6 bulan adalah 39,5\%.7 Sedangkan data SDKI tahun 2007, angka IMD 43,9\%, sementara pemberian ASI eksklusif sampai bayi berusia 6 bulan sebesar 32,4\%. Angka keberhasilan ASI eksklusif di Indonesia secara keseluruhan cenderung menurun. ${ }^{8}$

Salah satu langkah untuk meningkatkan angka pemberian ASI eksklusif yaitu dengan inisiasi menyusu dini (IMD). Inisiasi menyusu dini merupakan salah satu dari 10 langkah menuju keberhasilan menyusui (LMKM) yang diusung oleh WHO dan United Nations Children's Fund (UNICEF) melalui pembentukan baby friendly hospital initiative (BFHI) atau rumah sakit sayang bayi pada tahun 1991.,10

Penelitian yang mengkaji faktor yang memengaruhi pemberian ASI eksklusif telah banyak dilakukan baik di negara maju maupun negara berkembang, tetapi dengan hasil penelitian yang belum konklusif. Penelitian tersebut menemukan beberapa faktor yang memengaruhi keberhasilan pemberian ASI eksklusif, antara lain usia ibu $\geq 25$ tahun, ibu multipara, faktor fisis (kesehatan ibu), psikis ibu (keyakinan terhadap produksi ASI), tingkat pendidikan ibu yang tinggi, pengetahuan ibu tentang ASI eksklusif yang benar, status sosial ekonomi ibu yang tinggi, dukungan keluarga, dan konseling ASI dari petugas kesehatan. ${ }^{11-15}$

Penelitian di Indonesia mengenai faktor yang memengaruhi pemberian ASI eksklusif pada bayi IMD belum banyak dilakukan. Atas dasar masalah tersebut, penelitian ini bermaksud mengetahui faktor yang memengaruhi pemberian ASI eksklusif pada bayi yang dilakukan IMD di RS St Carolus.

\section{Metode}

Rancangan penelitian potong lintang analitik untuk mengetahui hubungan antara usia ibu, jumlah paritas, cara persalinan, faktor fisis, faktor psikis, ibu merokok, tingkat pendidikan ibu, ibu bekerja, pengetahuan ibu terhadap ASI eksklusif, status sosial ekonomi keluarga, dukungan keluarga, promosi susu formula, dan konseling ASI dengan pemberian ASI eksklusif pada bayi cukup bulan yang dilakukan IMD. Penelitian dilakukan di rumah sakit (RS) Sint (St) Carolus Jakarta, dimulai pada awal Juni hingga akhir September 2012. Populasi penelitian adalah bayi berusia 6-12 bulan yang datang ke Poliklinik Anak RS St. Carolus Jakarta. Kriteria inklusi adalah ibu yang memiliki bayi berusia 6-12 bulan, bayi dengan riwayat kelahiran cukup bulan yang lahir bugar melalui persalinan normal, persalinan dengan alat (vakum atau forsep), atau persalinan melalui bedah kaisar, bayi dilakukan IMD saat lahir, ibu bersedia menjadi subjek penelitian. Kriteria eksklusi adalah bayi dengan kelainan bawaan seperti labio-palato-gnatoskisis, kelainan jantung, spina bifida atau sindrom Down, dan bayi yang memiliki kontraindikasi menyusu, seperti lahir dari ibu HIV.

Ibu yang memiliki bayi berusia 6-12 bulan yang sesuai dengan kriteria inklusi penelitian akan dimintai informed consent untuk diikutsertakan dalam penelitian. Pengumpulan data dilakukan melalui wawancara mendalam menggunakan kuesioner tertulis. Subjek penelitian dibagi menjadi 2, yaitu kelompok ASI eksklusif dan ASI non-eksklusif. Analisis data menggunakan program SPSS versi 17.0. Dilakukan analisis bivariat dengan uji hipotesis Kai-kuadrat $\left(\mathrm{X}^{2}\right)$ hingga diperoleh nilai $\mathrm{p}$ untuk masing-masing faktor. Jika syarat uji Kai kuadrat tidak terpenuhi, dipakai uji Fisher. Analisis multivariat yang digunakan untuk melihat faktor yang paling memengaruhi pemberian ASI eksklusif yaitu uji regresi logistik.

\section{Hasil}

Rentang usia subjek antara 21-42 tahun dengan median usia 30 tahun. Sebagian besar subjek tercatat sebagai primipara atau melahirkan anak pertama (56,7\%). Sebagian besar subjek (65,8\%) melahirkan secara spontan dan sisanya melahirkan dengan bantuan vakum atau forsep $(9,2 \%)$ atau secara bedah kaisar (25\%). Karakteristik subjek penelitian tertera pada Tabel 1.

Proporsi bayi yang mendapatkan ASI eksklusif selama 6 bulan yaitu $75 \%$ (90 subjek). Rentang durasi 
Tabel 1. Karakteristik subjek penelitian

\begin{tabular}{|c|c|c|}
\hline Karakteristik & $\begin{array}{c}\text { Jumlah } \\
(\mathrm{n}=120)\end{array}$ & $(\%)$ \\
\hline \multicolumn{3}{|l|}{ Usia bayi (bulan) } \\
\hline $6-9$ & 81 & 67,5 \\
\hline$>9-12$ & 39 & 32,5 \\
\hline \multicolumn{3}{|l|}{ Jenis kelamin bayi } \\
\hline Lelaki & 66 & 55 \\
\hline Perempuan & 54 & 45 \\
\hline \multicolumn{3}{|l|}{ Usia Ibu (tahun) } \\
\hline$<25$ & 10 & 8,3 \\
\hline$\geq 25$ & 110 & 91,7 \\
\hline \multicolumn{3}{|l|}{ Jumlah Paritas } \\
\hline Primipara & 68 & 56,7 \\
\hline Multipara & 52 & 43,3 \\
\hline \multicolumn{3}{|l|}{ Cara persalinan } \\
\hline Spontan & 79 & 65,8 \\
\hline Operasi kaisar & 30 & 25 \\
\hline Vakum/Forsep & 11 & 9,2 \\
\hline \multicolumn{3}{|l|}{ Faktor fisis ibu } \\
\hline Ya & 27 & 22,5 \\
\hline Tidak & 93 & 77,5 \\
\hline \multicolumn{3}{|c|}{ Faktor psikis ibu (yakin kecukupan ASI) } \\
\hline $\mathrm{Ya}$ & 77 & 64,2 \\
\hline Tidak & 43 & 35,8 \\
\hline \multicolumn{3}{|l|}{ Ibu merokok } \\
\hline Ya & 0 & 0 \\
\hline Tidak & 120 & 100 \\
\hline \multicolumn{3}{|c|}{ Tingkat pendidikan ibu } \\
\hline Rendah & 0 & 0 \\
\hline Menengah & 32 & 26,7 \\
\hline Tinggi & 88 & 73,3 \\
\hline \multicolumn{3}{|l|}{ Ibu bekerja } \\
\hline Ya & 71 & 59,2 \\
\hline Tidak & 49 & 40,8 \\
\hline \multicolumn{3}{|c|}{ Pengetahuan ibu tentang ASI eksklusif } \\
\hline Benar & 102 & 85 \\
\hline Salah & 18 & 15 \\
\hline \multicolumn{3}{|c|}{ Sosial ekonomi keluarga } \\
\hline Rendah & 5 & 4,2 \\
\hline Menengah & 61 & 50,8 \\
\hline Tinggi & 54 & 45 \\
\hline \multicolumn{3}{|l|}{ Dukungan keluarga } \\
\hline Ya & 89 & 74,2 \\
\hline Tidak & 31 & 25,8 \\
\hline \multicolumn{3}{|c|}{ Promosi susu formula } \\
\hline Pernah & 44 & 36,7 \\
\hline Tidak pernah & 76 & 63,3 \\
\hline \multicolumn{3}{|l|}{ Konseling ASI } \\
\hline Ya & 88 & 73,3 \\
\hline Tidak & 32 & 26,7 \\
\hline
\end{tabular}

pemberian ASI pada bayi yang tidak mendapatkan ASI eksklusif bervariasi mulai dari 1 sampai 6 bulan (Gambar 1).

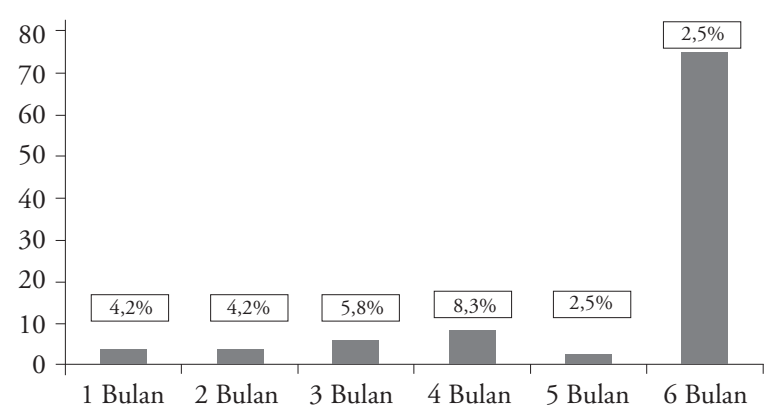

Gambar 1. Durasi pemberian ASI eksklusif

Tigapuluh subjek berhenti memberikan ASI eksklusif karena merasa produksi ASI tidak cukup atau sedikit. Alasan lain tertera pada Tabel 2.

Hasil analisis bivariat menunjukkan terdapat lima faktor yang memiliki hubungan bermakna dengan pemberian ASI eksklusif, yaitu pengetahuan ibu tentang ASI eksklusif, dukungan keluarga, promosi susu formula, konseling ASI, dan faktor psikis ibu. Terdapat satu variabel yaitu pengetahuan ibu yang tidak memenuhi syarat uji Kai kuadrat sehingga digunakan uji Fisher, sedangkan keempat variabel lain memenuhi syarat uji Kai kuadrat). Hasil uji bivariat tertera pada Tabel 3.

Analisis multivariat yang digunakan adalah regresi logistik dengan backward stepwise karena variabel yang diuji merupakan variabel kategorik. Berdasarkan uji regresi logistik didapatkan faktor yang paling bermakna memengaruhi ASI eksklusif secara berurutan, yaitu faktor psikis ibu dengan nilai RO 8,59 (IK 95\% 2,49-29,56; $\mathrm{p}=0,001$ ), diikuti oleh dukungan keluarga dengan nilai RO 6,25 (IK 95\% 1,92-20,35; p=0,002), dan pengetahuan ibu tentang ASI eksklusif dengan nilai RO 6,16 (IK 95\% 1,57-24,14; p=0,009), serta konseling ASI dengan nilai RO 5,86 (IK 95\% 1,720,13; $\mathrm{p}=0,005)$. Hasil analisis multivariat pada penelitian ini tertera pada Tabel 4.

\section{Pembahasan}

Kami mendapatkan proporsi ASI eksklusif 75\%. Nilai tersebut jauh lebih besar dibandingkan laporan dari Riset Kesehatan Dasar (RISKESDAS) tahun 2010 
Tabel 2. Alasan ibu berhenti memberikan ASI eksklusif

\begin{tabular}{lcc}
\hline Alasan & $\begin{array}{c}\text { Jumlah subjek } \\
(\mathrm{n}=30)\end{array}$ & $(\%)$ \\
\hline Ibu merasa produksi ASI tidak cukup & 13 & 43,3 \\
Bekerja & 8 & 26,7 \\
Campur tangan orangtua/mertua & 5 & 16,7 \\
Faktor fisis (puting mendatar dan mastitis) & 1 & 3,3 \\
Hiperbilirubinemia & 1 & 3,3 \\
Gagal tumbuh & 2 & 6,7 \\
\hline
\end{tabular}

Tabel 3. Hasil analisis bivariat terhadap faktor yang memengaruhi pemberian ASI eksklusif

\begin{tabular}{|c|c|c|c|c|}
\hline \multirow{2}{*}{ Variabel bebas } & \multicolumn{2}{|c|}{ ASI Eksklusif : n (\%) } & \multirow{2}{*}{ RO (IK 95\%) } & \multirow[b]{2}{*}{$\mathrm{p}$} \\
\hline & $\mathrm{Ya}$ & Tidak & & \\
\hline \multicolumn{5}{|l|}{ Usia Ibu (tahun) } \\
\hline$\geq 25$ & $84(76,4)$ & $26(23,6)$ & $2,15(0,56-8,20)$ & $0,216 \#$ \\
\hline$<25$ & $6(60)$ & $4(40)$ & & \\
\hline \multicolumn{5}{|l|}{ Jumlah paritas } \\
\hline Multipara & $39(75)$ & $13(25)$ & $0,95(0,41-2,20)$ & $1,000^{*}$ \\
\hline Primipara & $51(75)$ & $17(25)$ & & \\
\hline \multicolumn{5}{|l|}{ Cara persalinan } \\
\hline Spontan & $57(72,2)$ & $22(27,8)$ & $0,62(0,25-1,56)$ & $0,317^{*}$ \\
\hline Dengan tindakan & $33(80,5)$ & $8(19,5)$ & & \\
\hline \multicolumn{5}{|l|}{ Faktor fisis ibu } \\
\hline Tidak ada & $73(69,8)$ & $20(23,3)$ & $2,14 \quad(0,85-5,41)$ & $0,101^{*}$ \\
\hline Ada & $17(20,3)$ & $10(6,8)$ & & \\
\hline \multicolumn{5}{|c|}{ Faktor psikis ibu (yakin kecukupan ASI) } \\
\hline Ya & $68(88,3)$ & $9(11,7)$ & $7,21(2,88-18,04)$ & $0,000^{*}$ \\
\hline Tidak & $22(51,2)$ & $21(48,8)$ & & \\
\hline \multicolumn{5}{|l|}{ Ibu merokok } \\
\hline Tidak & $90(75)$ & $30(25)$ & N/A & N/A \\
\hline Ya & 0 & 0 & & \\
\hline \multicolumn{5}{|c|}{ Tingkat pendidikan Ibu } \\
\hline Tinggi & $67(76,1)$ & $21(23,9)$ & $1,24(0,5-3,11)$ & $0,634^{*}$ \\
\hline Menengah & $23(71,9)$ & $9(28,1)$ & & \\
\hline \multicolumn{5}{|l|}{ Pekerjaan ibu } \\
\hline Tidak bekerja & $39(79,5)$ & $10(20,5)$ & $1,52(0,64-3,63)$ & $0,335^{*}$ \\
\hline Bekerja & $51(71,8)$ & $20(28,2)$ & & \\
\hline \multicolumn{5}{|l|}{ Pengetahuan ibu } \\
\hline Benar & $84(82,4)$ & $18(17,6)$ & $9,33(3,09-28,16)$ & $0,000^{*}$ \\
\hline Salah & $6(33,3)$ & $12(66,7)$ & & \\
\hline \multicolumn{5}{|l|}{ Status sosial ekonomi } \\
\hline Tinggi & $45(38,3)$ & $9(16,7)$ & $2,33(0,96-5,64)$ & $0,057^{*}$ \\
\hline \multirow{2}{*}{\multicolumn{5}{|c|}{ Dukungan keluarga }} \\
\hline & & & & \\
\hline Ya & $75(84,3)$ & $14(15,7)$ & $5,71(2,30-14,14)$ & $0,000^{*}$ \\
\hline Tidak & $15(48,4)$ & $16(51,6)$ & & \\
\hline \multicolumn{5}{|l|}{ Promosi susu formula } \\
\hline Tidak pernah & $62(81,5)$ & $14(18,5)$ & $2,5(1,08-5,89)$ & $0,029^{*}$ \\
\hline Pernah & $28(63,6)$ & $16(36,4)$ & & \\
\hline \multicolumn{5}{|l|}{ Konseling ASI eksklusif } \\
\hline Ya & $74(84,1)$ & $14(15,9)$ & $5,28(2,15-12,97)$ & $0,000^{*}$ \\
\hline Tidak & $16(50)$ & $16(50)$ & & \\
\hline
\end{tabular}

* Uji Kai kuadrat,

\# Uji Fisher

$\mathrm{p}<0,05$ (bermakna secara statistik) 
Tabel 4. Analisis multivariat faktor yang memengaruhi pemberian ASI eksklusif

\begin{tabular}{|c|c|c|c|c|c|c|c|}
\hline Variabel & $\mathrm{B}$ & S.E. & Wald & Df & $\mathrm{p}$ & $\mathrm{RO}$ & IK 95\% \\
\hline \multicolumn{8}{|l|}{ Langkah $1^{a}$} \\
\hline Usia ibu (1) & $-1,762$ & 1,126 & 2,448 & 1 & 0,118 & 0,172 & $0,01-1,56$ \\
\hline Faktor fisis (1) & 0,675 & 0,672 & 1,008 & 1 & 0,315 & 1,964 & $0,52-7,33$ \\
\hline Faktor psikis (1) & 2,299 & 0,674 & 11,649 & 1 & 0,001 & 9,965 & $2,66-37,31$ \\
\hline Pengetahuan ibu (1) & 1,740 & 0,732 & 5,651 & 1 & 0,017 & 5,696 & $1,35-23,91$ \\
\hline Sosial ekonomi (1) & 0,885 & 0,664 & 1,777 & 1 & 0,183 & 2,424 & $0,65-8,90$ \\
\hline Dukungan keluarga (1) & 1,847 & 0,626 & 8,696 & 1 & 0,003 & 6,343 & $1,85-21,65$ \\
\hline Promosi susu formula (1) & 0,984 & 0,669 & 2,162 & 1 & 0,141 & 2,676 & $0,72-9,93$ \\
\hline Konseling ASI (1) & 1,560 & 0,662 & 5,555 & 1 & 0,018 & 4,758 & $1,30-17,41$ \\
\hline Konstanta & $-3,596$ & 1,364 & 6,951 & 1 & 0,008 & 0,027 & \\
\hline \multicolumn{8}{|l|}{ Langkah $2^{\mathrm{a}}$} \\
\hline Usia ibu (1) & $-1,790$ & 1,114 & 2,583 & 1 & 0,108 & 0,167 & $0,01-1,48$ \\
\hline Faktor psikis (1) & 2,348 & 0,665 & 12,470 & 1 & 0,000 & 10,465 & $2,84-38,52$ \\
\hline Pengetahuan ibu (1) & 1,685 & 0,718 & 5,505 & 1 & 0,019 & 5,394 & $1,32-22,04$ \\
\hline Sosial ekonomi (1) & 1,019 & 0,652 & 2,447 & 1 & 0,118 & 2,771 & $0,77-9,93$ \\
\hline Dukungan keluarga (1) & 1,908 & 0,621 & 9,432 & 1 & 0,002 & 6,737 & $1,99-22,75$ \\
\hline Promosi susu formula (1) & 0,934 & 0,661 & 2,000 & 1 & 0,157 & 2,545 & $0,69-9,28$ \\
\hline Konseling ASI(1) & 1,496 & 0,656 & 5,201 & 1 & 0,023 & 4,466 & $1,23-16,15$ \\
\hline Konstanta & $-3,068$ & 1,239 & 6,134 & 1 & 0,013 & 0,047 & \\
\hline \multicolumn{8}{|l|}{ Langkah $3^{\mathrm{a}}$} \\
\hline Usia ibu (1) & $-1,734$ & 1,108 & 2,449 & 1 & 0,118 & 0,177 & $0,02-1,55$ \\
\hline Faktor psikis (1) & 2,151 & 0,630 & 11,642 & 1 & $0,001^{*}$ & 8,593 & $2,49-29,56$ \\
\hline Pengetahuan ibu (1) & 1,819 & 0,696 & 6,826 & 1 & $0,009^{*}$ & 6,167 & $1,57-24,14$ \\
\hline Sosial ekonomi (1) & 1,087 & 0,641 & 2,878 & 1 & 0,090 & 2,966 & $0,84-10,41$ \\
\hline Dukungan keluarga (1) & 1,833 & 0,602 & 9,272 & 1 & $0,002^{*}$ & 6,255 & $1,92-20,35$ \\
\hline Konseling ASI(1) & 1,768 & 0,630 & 7,888 & 1 & $0,005^{*}$ & 5,861 & $1,70-20,13$ \\
\hline Konstanta & $-2,694$ & 1,189 & 5,130 & 1 & 0,024 & 0,068 & \\
\hline
\end{tabular}

a. Variabel yang dimasukan pada langkah 1: usia ibu, pengatahuan ibu, status sosial ekonomi, dukungan keluarga, promosi susu formula, konseling ASI, faktor psikis ibu, dan faktor fisis ibu (8 variabel)

b. $\quad{ }^{*} \mathrm{p}<0,05$ (bermakna secara statistik)

(15\%) dan data SDKI 2007 (32\%). ${ }^{8,16}$ Angka proporsi ASI eksklusif yang didapatkan lebih besar dibandingkan di beberapa negara lain. Prevalensi ASI eksklusif beberapa negara, antara lain Malaysia 32,8\%, ${ }^{11}$ India 61,5\%, ${ }^{17}$ dan Brazil 31\%. ${ }^{18}$ Proporsi ASI eksklusif yang tinggi pada penelitian kami disebabkan RS St Carolus sudah mengimplementasikan program baby friendly hospital initiative (BFHI) atau rumah sakit sayang bayi yang direkomendasikan oleh WHO dan UNICEF sejak tahun 1990. Implementasi BFHI terbukti dapat meningkatkan angka pemberian ASI eksklusif.
Tigapuluh subjek gagal meneruskan pemberian ASI eksklusif, alasan terbanyak karena ibu merasa produksi ASI-nya tidak cukup atau sedikit. Sebagian besar subjek (54\%) yang merasa produksi ASI-nya sedikit mengaku tidak melakukan konseling lebih lanjut dengan petugas kesehatan di RS St Carolus dan memutuskan sendiri untuk memberikan susu formula kepada bayinya. Delapan subjek berhenti memberikan ASI eksklusif karena harus kembali bekerja. Mereka beralasan karena ASI yang keluar hanya sedikit pada saat diperah, sedangkan jika disusui secara langsung produksi ASI banyak sehingga saat ibu di rumah, bayi diberikan ASI, 
sementara saat ibu bekerja bayi diberikan susu formula. Lima subjek gagal memberikan ASI eksklusif karena campur tangan ibu atau mertua. Kelima subjek tersebut tinggal di rumah ibu atau mertua sehingga subjek gagal memberikan ASI eksklusif karena dominasi dari ibu atau mertua terhadap pengasuhan anak, termasuk pola pemberian makanannya.

Tidak didapatkan perbedaan pemberian ASI eksklusif antara kelompok ibu yang berusia $\geq 25$ tahun dengan $<25$ tahun. Hasil penelitian kami memberikan informasi yang berbeda dengan hasil penelitian di Kolumbia, ${ }^{19}$ Kanada, ${ }^{12}$ dan Australiaa ${ }^{20,21}$ yang menemukan hubungan usia ibu dengan pemberian ASI eksklusif. Pada penelitian tersebut, proporsi ASI eksklusif dijumpai lebih tinggi pada kelompok ibu yang berusia lebih tua. Diskon gruensi hasil penelitian ini disebabkan terdapat perbedaan yang ekstrim antara jumlah ibu yang berusia $\geq 25$ tahun $(91,7 \%)$ dan $<25$ tahun $(8,3 \%)$, dan peneliti menemukan $33 \%$ kelompok ibu yang berusia $<25$ tahun telah memperoleh konseling ASI sejak hamil sehingga berhasil memberikan ASI eksklusif hingga 6 bulan.

Kami menemukan tidak terdapat perbedaan pemberian ASI eksklusif antara primipara dan multipara. Proporsi ASI eksklusif yang tinggi pada ibu primipara karena sebagian besar (60\%) sudah memperoleh konseling ASI sejak masa kehamilan. Program BFHI di RS St Carolus memuat kebijakan LMKM, khususnya poin nomor 3, yaitu petugas kesehatan harus memberikan penjelasan dan informasi tentang manfaat dan tata laksana menyusui kepada ibu hamil.

Kami menemukan tidak terdapat hubungan antara cara persalinan dengan pemberian ASI eksklusif. Pada penelitian kami, ibu sejak hamil trimester ketiga sudah mendapatkan penyuluhan prenatal antara lain mengenai kemungkinan cara persalinan yang akan dihadapi tidak memengaruhi ASI eksklusif. Selain itu, tim persalinan baik pada persalinan dengan alat maupun bedah kaisar, yang terdiri dari dokter spesialis kandungan dan kebidanan, dokter anak, bidan dan perawat berkomitmen melakukan IMD, dan saling bekerja sama untuk terlaksananya proses IMD.

Faktor fisis ibu tidak memiliki hubungan dengan pemberian ASI eksklusif. Penyebab rendahnya proporsi subjek yang memiliki masalah faktor fisis seperti puting lecet, dan atau mastitis karena ibu yang melahirkan di RS St Carolus diberikan penyuluhan breastcare yang bertujuan meningkatkan pengetahuan ibu tentang perawatan payudara, pijat payudara, mengatasi puting yang mendatar, dan mencegah payudara bengkak dan ibu diharapkan dapat mempraktekannya sendiri. Penyuluhan breastcare tersebut diberikan sejak mulai usia kehamilan minimal 28 minggu, berkesinambungan hingga hari ketiga post-partum. ${ }^{22}$

Faktor psikis ibu memiliki hubungan dengan pemberian ASI eksklusif. Beberapa penelitian di Amerika dan Australia sepakat bahwa faktor psikis ibu berpengaruh pada pemberian ASI eksklusif. Faktor psikis yang positif seperti rasa percaya diri yang kuat, merasa yakin akan kecukupan ASI, tidak stres dan sikap positif terhadap menyusui turut menunjang keberhasilan ASI eksklusif. ${ }^{23}$ Persepsi ibu terhadap ketidakcukupan ASI lebih disebabkan oleh psikologis ibu daripada masalah biologis. Ibu yang merasa produksi ASI-nya kurang, cenderung memiliki rasa percaya diri yang rendah dalam menyusui, tetapi ibu yang percaya bahwa dirinya mampu menyusui dan mampu menghadapi tantangan dan kesulitan menyusui, cenderung merasa bahwa produksi ASI-nya cukup..$^{24,25}$

Tingkat pendidikan tidak memengaruhi pemberian ASI eksklusif selama 6 bulan. Kami menemukan ibu yang berpendidikan menengah tidak kalah dalam hal mencari pengetahuan dan wawasan mengenai ASI melalui situs internet, komunitas jejaring sosial facebook, tweeter, dan blackberry group. Melalui komunitas sosial tersebut, mereka berbagi informasi mengenai ASI dan diskusi mengenai masalah dan kesulitan selama menyusui. Hal inilah yang menjadi salah satu faktor pendukung keberhasilan ASI eksklusif pada kelompok ibu berpendidikan menengah.

Hasil analisis bivariat menunjukkan status ibu bekerja tidak memengaruhi pemberian ASI eksklusif. Proporsi ASI eksklusif yang tinggi pada kelompok ibu bekerja disebabkan ibu yang bekerja sudah dibekali pengetahuan yang cukup mengenai cara mempertahankan pemberian ASI eksklusif selama bekerja. Pengetahuan tersebut sudah mereka dapatkan sebelum cuti melahirkan berakhir, bahkan konseling ASI sejak hamil sehingga pada saat ibu harus kembali bekerja, mereka tidak menemukan masalah dan hambatan. Konseling pemberian ASI eksklsuif pada ibu bekerja meliputi cara pemberian ASI perah, cara menyimpan ASI perah di dalam freezer, dan cara memompa ASI. 
Pengetahuan ibu yang benar mengenai ASI eksklusif didapatkan bermakna dengan pemberian ASI eksklusif. Hasil penelitian kami sesuai dengan penelitian potong lintang yang dilakukan di Tanzania yang menemukan kelompok ibu dengan pengetahuan ASI yang cukup memiliki kemungkinan 5,4 kali lebih besar untuk ASI eksklusif selama 6 bulan. ${ }^{26}$ Tingginya proporsi ibu yang memiliki pengetahuan yang benar mengenai ASI ekslusif merupakan kontribusi dari beberapa faktor, seperti kebijakan di RS St Carolus yang mengimplementasikan BFHI, efektifnya edukasi mengenai ASI eksklusif secara umum di masyarakat, dan meningkatnya dukungan menyusui dari kelompok pendukung ASI (KP-ASI).

Hasil analisis bivariat menunjukkan tingkat sosial ekonomi tidak berhubungan dengan pemberian eksklusif. Hasil serupa didapatkan oleh Heather $\mathrm{dkk}^{12}$ di Kanada tahun 2009 dan Marques dkk ${ }^{27}$ di Brazil tahun 2001 yang menemukan tingkat sosial ekonomi tidak memengaruhi pemberian ASI eksklusif. Sementara penelitian kohort yang dilakukan di kota Pelotas, Brazil, tahun 2003 menyimpulkan status sosial ekonomi yang rendah memengaruhi kegagalan ASI eksklusif. Perbedaannya dengan penelitian yang dilakukan peneliti, penelitian di Pelotas menggunakan batasan operasional ASI eksklusif dengan durasi 3 bulan, dan desain penelitian yang digunakan adalah kohort.

Hasil analisis bivariat dan multivariat menunjukkan terdapat hubungan antara dukungan menyusui dari keluarga dengan pemberian ASI eksklusif. Bukti bahwa dukungan sosial terhadap menyusui berpengaruh positif terhadap durasi ASI eksklusif sudah banyak dibuktikan di beberapa penelitian di banyak negara. ${ }^{28-32}$ Berbagai macam upaya dukungan dalam peningkatan pemberian ASI, berawal dari dukungan suami dan keluarga. Jika ibu merasa didukung, dicintai, dan diperhatikan maka akan muncul emosi positif yang akan meningkatkan produksi hormon oksitosin sehingga produksi ASI pun lancar. ${ }^{12,28}$

Pada penelitian kami, 36,7\% subjek mengaku pernah mendapat promosi susu formula secara langsung, baik di rumah, swalayan, dan tempat umum lainnya. Pada analisis bivariat, terdapat perbedaan pemberian ASI eksklusif antara kelompok ibu yang pernah mendapat promosi susu formula dan yang tidak, tetapi hal ini tidak terbukti pada analisis multivariat. Berdasarkan wawancara mendalam yang dilakukan oleh peneliti terhadap beberapa subjek, ketertarikan ibu terhadap susu formula dirasakan terutama saat bulan-bulan pertama menyusui di saat masalah menyusui muncul, seperti produksi ASI belum banyak, puting lecet, dan payudara bengkak. Peran pemerintah dalam memperketat regulasi pemasaran susu formula bayi sangat diperlukan.

Hasil analisis multivariat yang tidak bermakna dapat disebabkan oleh keterbatasan definisi operasional "promosi susu formula" yang digunakan oleh peneliti, yaitu "penawaran produk susu formula secara langsung atau pemberian susu formula gratis kepada ibu". Kami mendapatkan ibu-ibu tersebut memperoleh promosi susu formula di rumah, di tempat umum, dan di pasar swalayan (mall). Sedangkan di RS Carolus sendiri, tidak dijumpai adanya praktek promosi susu formula baik secara langsung maupun tidak langsung. Hasil penelitian akan berbeda jika batasan operasional yang digunakan berupa pembagian susu formula gratis oleh petugas kesehatan dan penelitian dilakukan di rumah sakit yang belum menjalankan program BFHI.

Pemerintah juga telah megeluarkan peraturan mengenai pemasaran susu formula yaitu Kepmenkes No. 237/Menkes/SK/IV/1997 tentang pemasaran pengganti ASI yang telah melarang mengiklankan susu formula bayi, pembagian sampel gratis pada sarana pelayanan kesehatan, ibu hamil atau melahirkan. ${ }^{33}$ Pengawasan terhadap pelaksanaan ketentuan ini serta sanksi yang jelas dan tegas masih belum tercapai sehingga pelanggaran yang berkaitan dengan promosi susu formula masih terus berjalan.

Uji regresi logistik menunjukkan faktor yang paling memengaruhi pemberian ASI eksklusif adalah faktor psikis ibu, diikuti oleh dukungan keluarga, pengetahuan ibu tentang ASI eksklusif, dan konseling ASI oleh petugas kesehatan. Jika seorang ibu memiliki keyakinan terhadap produksi ASI, pengetahuan yang benar tentang ASI eksklusif, dukungan keluarga untuk menyusui dan memperoleh konseling minimal 3 kali dari petugas kesehatan maka probabili tas ibu tersebut untuk memberikan ASI eksklusif kepada bayinya adalah sebesar $99,2 \%$.

\section{Kesimpulan}

Proporsi ASI eksklusif pada bayi cukup bulan yang dilakukan IMD di RS St Carolus adalah 75\%. Faktor yang terbukti memengaruhi pemberian ASI eksklsusif adalah faktor psikis ibu (keyakinan ibu terhadap 
produksi ASI), dukungan keluarga, pengetahuan ibu yang benar tentang ASI eksklusif, dan konseling ASI dari petugas kesehatan.

\section{Daftar pustaka}

1. Work Group On Breastfeeding. American Academy Of Pediatrics. Breastfeeding and the use of human milk. Pediatrics 1997;100:1035-9.

2. Besar Ds, Eveline Pn. Air susu ibu dan hak bayi. Dalam: Hegar B, Suradi R, Hendarto A, Partiwi IGA, penyunting. Bedah ASI. Jakarta: IDAI; 2008. h.1-16.

3. Suradi R. Manajemen laktasi. Dalam: Suradi R, Tobing HK, penyunting. Jakarta: Perinasia; 2007. h.1-5.

4. World Health Organization. The Optimal Duration Of Exclussive Breastfeeding. 2002. (Diakses Tanggal 2 Maret 2011) Geneva: Diunduh dari: Http://Www. Who.Int/Nut/ Inf.Htm.

5. Departemen Kesehatan RI. Keputusan Menteri Kesehatan Ri No. 450/Menkes/Sk/2004 tentang pemberian air susu ibu secara eksklusif pada bayi di Indonesia. (Diakses Tanggal 2 November 2012). Diunduh dari:Http//Depkes. Go.Id/Menkes_Content.

6. Departemen Kesehatan RI. Undang-Undang Republik Indonesia No. 36 Tahun 2009 tentang kesehatan. (Diakses Tanggal 2 November 2012). Diunduh dari: Http://Depkes.Go.Id/Uu_Content.

7. Suradi R. Menempatkan kembali peran air susu ibu dalam pembinaan tumbuh kembang bayi dan anak. Disampaikan pada upacara pengukuhan sebagai guru besar tetap dalam ilmu kesehatan anak pada Fakultas Kedokteran Universitas Indonesia. Jakarta, 2004.

8. Badan Statistik Nasional, Badan Koordinasi Keluarga Berencana Nasional, Departemen Kesehatan. Survey Demografi Dan Kesehatan Indonesia 2007. Jakarta: Badan Pusat Statistik, 2008.

9. World Health Organization, Division of Child Health And Development, Family And Reproductive Health. Evidence for the steps for successful breastfeeding. Genewa: World Health Organization; 1998.h.31-4.

10. United Nations Children's Fund, World Health Organization. Baby-friendly hospital initiative revised, updated and expanded for integrated care. Genewa: Unicef-WHO; 2006.

11. Leong Tk. Knowledge, attitude and practice on breastfeeding in Klang, Malaysia. Int Malay J 2009;8:1721.
12. Heather Lk, Katie Hc, Suzanne Ct. Risk factor for cessation of breastfeeding prior to six months postpartum among a community sampel of woman in Calgary, Alberta. Can J of Pub Health 2009;68:1-4.

13. Al-Sahab B, Tamim H, Mumtaz G, Khawaja G, Khogali M, Afifi R, dkk. Predictors of breastfeeding in a developing country: result of a prospective cohort study. Pub Health Nutr 2008;12:1350-6.

14. Butler S, Williams M, Tukuitonga C, Paterson C. Factor associated with not breastfeeding exclussively among mothers of a cohort of pacific infants in New Zealand. J New Zealand Med Ass 2004;117:1-10.

15. Mascarenhas Ml, Albernaz E, Silva M, Silveira RB. Prevalence of exclussive breastfeeding and its determiners in the first 3 months of life in The South Brazil. J Pediatr 2006;82:289-94.

16. Badan Penelitian dan Pengembangan Kementrian Kesehatan RI. Riset Kesehatan Dasar 2010. (Diakses Tanggal 12 September 2012). Diunduh dari: Http:// Depkes. Go.Id/Riskesdas.Files.

17. Sapna P, Ameya H, Rooma P, Aarti P, Rashid AK, Narayan KA. Prevalence of exclussive breastfeeding and its correlate in an urban slum in Western India. Iejsme 2009;2:14-8.

18. Narchi NZ, Fernandes RA, Dias LD, Novais DH. Variables that influence the maintenance of exclussive breastfeeding. Rev Esc Enferm Usp 2009;43:83-90.

19. Jones G, Steketee RW, Black RE, Bhutta ZA, Morris SS. Child survival II: how many child deaths can we prevent this year? Lancet 2003;362:65-71.

20. Hauck YL Fenwick J, Dhaliwal SS, Butt J. A Western Australian survey of breastfeeding initiation,prevalence and early cessation patterns. Matern Child Health J 2011;15:260-8.

21. Cooklin AR, Donath SM, Amir LH. Maternal employment and breastfeeding: result from the longitudinalstudy of Australian children. Acta Pediatr 2008;97:620-3.

22. Roesli U. Lembaga peningkatan penggunaan ASI Sint Carolus. Makalah Ilmiah Pribadi. Jakarta; 1998.

23. Taveras EM, Capra AM, Braveman PA, Jensvold NG, Escobar GJ, Lieu TA. Clinician support and psychosocial risk factor associated with breastfeeding discontinuation. Pediatrics 2003;112:108-15.

24. Mccarter D, Kearney M. Parenting self-efficacy and perception of insufficient breastmilk. J Obs Gyn 2001;30: 515-22.

25. Blyth R, Creedy D, Dennis Cl, Moylew, Pratt J, De Vries S. Effect of maternal confidence on breastfeeding duration: an application of breastfeeding self-efficacy 
theory. Birth 2002;29:278-84.

26. Nkala TE, Msuya SE. Prevalence and predictors of exclussive breastfeeding among women in Kigoma Region, Western Tanzania: a community based crosssectional study. Int Breastfeed J 2011;6:1-7.

27. Marques SM, Lira PI, Lima MC, Da-Silva NI, Filho MB, Huttky SR. Breastfeeding and early weaning practice in Northeast Brazil: a longitudinal. Breastfeed J 2001;108:1-7.

28. Wolfberg A, Michels K, Shields W, O'campo P, Bronner Y, Bienstock J. Dads as breastfeeding advocates: results from a randomized controlled trial of an education intervention. Am J Obs Gyn 2004;191:708-12.

29. Win N, Binns C, Zhao Y, Scotte J, Oddy W. Breastfeeding duration in mothers who express breastmilk: a cohort study. Intl Breastfeed J 2006:1-28.

30. Britton C, Mccormic F, Renfrew M, Wade A, King S. Support for breastfeeding mothers. Cochrane Database Syst Revs 2007;34:1-22.

31. Sikorski J, Renfrew M, Pindoria S, Wade A. Support for breastfeeding mothers: a systematic review. Paediatrics 2003;17:407-17.

32. Falceto O, Giugliani E, Fernandes C. Couples' relationships and breastfeeding: is there an association? J Human Lact 2004;20:46-55.

33. Kementrian Kesehatan Republik Indonesia. Keputusan Menteri Kesehatan Republik Indonesia No. 237/ Menkes/Sk/1v/1997 Tentang Pemasaran Pengganti Asi. (Diakses Tanggal 2 November 2011). Diunduh Dari: Http://Gizi.Depkes.Go.Id/Kepmenkes/1997.Pdf. 